\title{
Epidemic Development of Hawthorn Leaf Blight (Monilinia johnsonii) on Mayhaw (Crataegus aestivalis and C. opaca) in Georgia
}

\author{
H. Scherm and A. T. Savelle, Department of Plant Pathology, University of Georgia, Athens 30602
}

\begin{abstract}
Scherm, H., and Savelle, A. T. 2003. Epidemic development of hawthorn leaf blight (Monilinia johnsonii) on mayhaw (Crataegus aestivalis and C. opaca) in Georgia. Plant Dis. 87:539-543.

Mayhaws are small trees and shrubs in the hawthorn genus, Crataegus. They are native to the southern United States, where their fruit is highly valued for use in jellies and preserves. Since 1997, symptoms of hawthorn leaf blight, caused by Monilinia johnsonii, have been observed in mayhaw orchards in southwestern Georgia. We studied epidemic development of the disease in a mixed planting of Crataegus aestivalis (eastern mayhaw) and $C$. opaca (western mayhaw) between 2000 and 2002. Apothecia of M. johnsonii were first observed in early to mid-February on overwintered, mummified fruit of $C$. aestivalis; no apothecia were detected in plots underneath $C$. opaca trees. Both mayhaw species exhibited moderate to severe leaf blighting beginning in early March, although some genotypes within each species apparently escaped primary infection via delayed leaf bud break or a slower rate of leaf expansion. On a per-tree basis, leaf blight incidence was positively correlated with mean leaf length during the period when apothecia were most numerous $(r=0.7225, P=0.0003, n=20)$. Fruit mummification, which results from secondary infection of open flowers by conidia, was widespread by late March to early April and was significantly $(P<0.05)$ more severe on $C$. aestivalis, most likely because trees of this species were at an earlier bloom stage when conidia-bearing blighted leaves were first observed. By contrast, $C$. opaca advanced through bloom earlier, thereby partly escaping secondary infection. On a per-tree basis, there was no relationship between incidence levels of leaf blight and fruit infection for either species; indeed, some trees with the lowest incidence of leaf blight had the greatest incidence of fruit mummification and vice versa. Thus, in a mixed planting of different mayhaw genotypes, conidia appear to be dispersed readily from heavily blighted trees, leading to high levels of fruit infection even in trees with negligible incidence of leaf blight. There are genotypes within both mayhaw species that almost completely avoid either primary infection or secondary infection; therefore, planting such genotypes in pure stands may aid in minimizing losses due to the disease.
\end{abstract}

Mayhaws are small, deciduous trees and shrubs in the hawthorn genus, Crataegus, that are locally abundant in wet areas and swamps in the southern United States (15). Their aromatic fruit are highly valued for use in jellies and preserves (2). In recent years, demand has exceeded local supply of fruit collected from native stands, leading to increased interest in commercial production (14). Consequently, several commercial mayhaw orchards have been established in southern Georgia and northern Florida $(10,11)$. Only a few named cultivars are available and little is known about their performance in commercial conditions. Therefore, these orchards generally are mixed plantings of various genotypes of the two species Crataegus aestivalis (eastern mayhaw) and $C$. opaca (western mayhaw). The former species is native to northern Florida, southern Geor-

Corresponding author: H. Scherm

E-mail: scherm@uga.edu

Accepted for publication 2 December 2002.

Publication no. D-2003-0224-02R

(C) 2003 The American Phytopathological Society gia, and the Carolina coast; trees generally bloom in early to mid-March, and fruit ripen by early to mid-May. C. opaca is indigenous to eastern Texas and Louisiana, and bloom and fruit maturity occur earlier than on $C$. aestivalis (mid-February to mid-March and mid-April to early May, respectively). A detailed taxonomic account of the two species has been given by Phipps (15).

Since 1997, symptoms of leaf blight and fruit mummification caused by the ascomycete Monilinia johnsonii (Ellis \& Everh.) Honey have been observed sporadically in commercial mayhaw orchards in southwestern Georgia (11). This fungus, known as the causal agent of hawthorn leaf blight $(1,7-9,13)$, affects many species within the genus Crataegus $(1,3)$. On mayhaw, the disease is initiated in late winter by ascospore infection of young, expanding vegetative tissues around or shortly after leaf bud break, causing the foliage to blight. The ascospores are released from apothecia formed on overwintered, mummified fruit on the ground. Conidia, produced on blighted leaves in early spring, infect open flowers via the stigma-style pathway (13), leading to mummification and drop of the immature fruit. There is only one cycle each of ascospore infection (primary infection) and conidial infection (secondary infection) per year.

Severe outbreaks of the disease in a research mayhaw orchard in southwestern Georgia between 2000 and 2002 allowed its epidemic development to be studied without interference by commercial disease management practices (16). This report summarizes key epidemiological features of this pathosystem.

\section{MATERIALS AND METHODS}

The experimental site was a mature, drip-irrigated planting of different genotypes of $C$. aestivalis (99 trees) and $C$. opaca (21 trees) at the University of Georgia's Attapulgus Research and Education Center in Decatur County. All trees of $C$. aestivalis originally had been collected as seedlings from native sites in southern Georgia and northern Florida, whereas those of C. opaca had been obtained as grafted cultivars. The two species were grown in separate rows within the same orchard block; spacing was $4.6 \mathrm{~m}$ within rows and $6.1 \mathrm{~m}$ between rows. The orchard was managed as described previously (10), but no fungicides were applied during the study period. Weather variables were monitored with an on-site agrometeorological station (6).

2000 experiment. On each of 12 arbitrarily selected trees of each mayhaw species, six 75-cm-long shoots were tagged during early bloom in late February. During March and early April, leaf blight incidence was determined by counting the number of affected leaves on each tagged shoot and expressing it as a percentage of the total number of leaves per shoot; all data on leaf blight incidence reported below are from the final assessment date. Incidence of fruit mummification was determined twice during late March and midApril by removing infected fruit and expressing the total number of diseased fruit on each tagged shoot as a percentage of the total number of fruit per shoot. Fruit numbers were variable among shoots; therefore, mean fruit disease incidence per tree was calculated as a weighted average using incidence values from individual shoots weighted by the total number of fruit per shoot.

2001 and 2002 experiments. Five trees of each species (a subset of the trees used in 2000) were selected for more detailed observation (Table 1). Throughout February 
Table 1. Incidence of leaf blight and fruit mummification caused by Monilinia johnsonii on different mayhaw genotypes in a research orchard in southwestern Georgia in 2001 and 2002

\begin{tabular}{|c|c|c|c|c|}
\hline \multirow[b]{2}{*}{ Mayhaw species and cultivar or selection ${ }^{b}$} & \multicolumn{2}{|r|}{2001} & \multicolumn{2}{|c|}{2002} \\
\hline & Leaf blight (\%) & Fruit mummification (\%) & Leaf blight (\%) & Fruit mummification (\%) \\
\hline \multicolumn{5}{|l|}{ Crataegus aestivalis } \\
\hline 26 (Dougherty east) & $22.8 \pm 2.9$ & $96.6 \pm 2.3$ & $29.6 \pm 3.9$ & $88.4 \pm 2.5$ \\
\hline 43 (unknown) & $0.0 \pm 0.0$ & $78.3 \pm 8.9$ & $4.0 \pm 1.2$ & $66.7 \pm 9.4$ \\
\hline 48 (Dougherty west) & $0.9 \pm 0.7$ & $46.0 \pm 5.8$ & $4.0 \pm 2.5$ & $36.7 \pm 9.1$ \\
\hline 70 (Decatur) & $45.5 \pm 10.6$ & $80.0 \pm 9.4$ & $35.3 \pm 6.6$ & $47.1 \pm 9.8$ \\
\hline 88 (Terrell) & $35.3 \pm 5.8$ & $90.0 \pm 4.9$ & $67.3 \pm 1.3$ & $75.8 \pm 9.9$ \\
\hline \multicolumn{5}{|l|}{ C. opaca } \\
\hline Elite & $42.9 \pm 3.6$ & $4.0 \pm 1.0$ & $66.4 \pm 9.1$ & $0.0 \pm 0.0$ \\
\hline Mason's Superberry & $23.3 \pm 2.9$ & $28.6 \pm 10.9$ & $68.3 \pm 4.9$ & $5.6 \pm 2.7$ \\
\hline Royalty & $0.0 \pm 0.0$ & $31.2 \pm 5.7$ & $0.9 \pm 0.9$ & $40.4 \pm 7.2$ \\
\hline Saline & $0.0 \pm 0.0$ & $20.4 \pm 3.7$ & $3.4 \pm 1.0$ & $14.4 \pm 2.5$ \\
\hline Vernon & $8.4 \pm 5.9$ & $12.2 \pm 11.4$ & $21.8 \pm 5.6$ & $0.0 \pm 0.0$ \\
\hline
\end{tabular}

${ }^{a}$ Values are means \pm standard errors of six 75 -cm-long shoots per tree. For fruit mummification data, incidence values from individual shoots were weighted by the total number of fruit per shoot.

${ }^{\mathrm{b}}$ For C. aestivalis, designations indicate selection number followed by seedling collection site (county) in parentheses.

2001
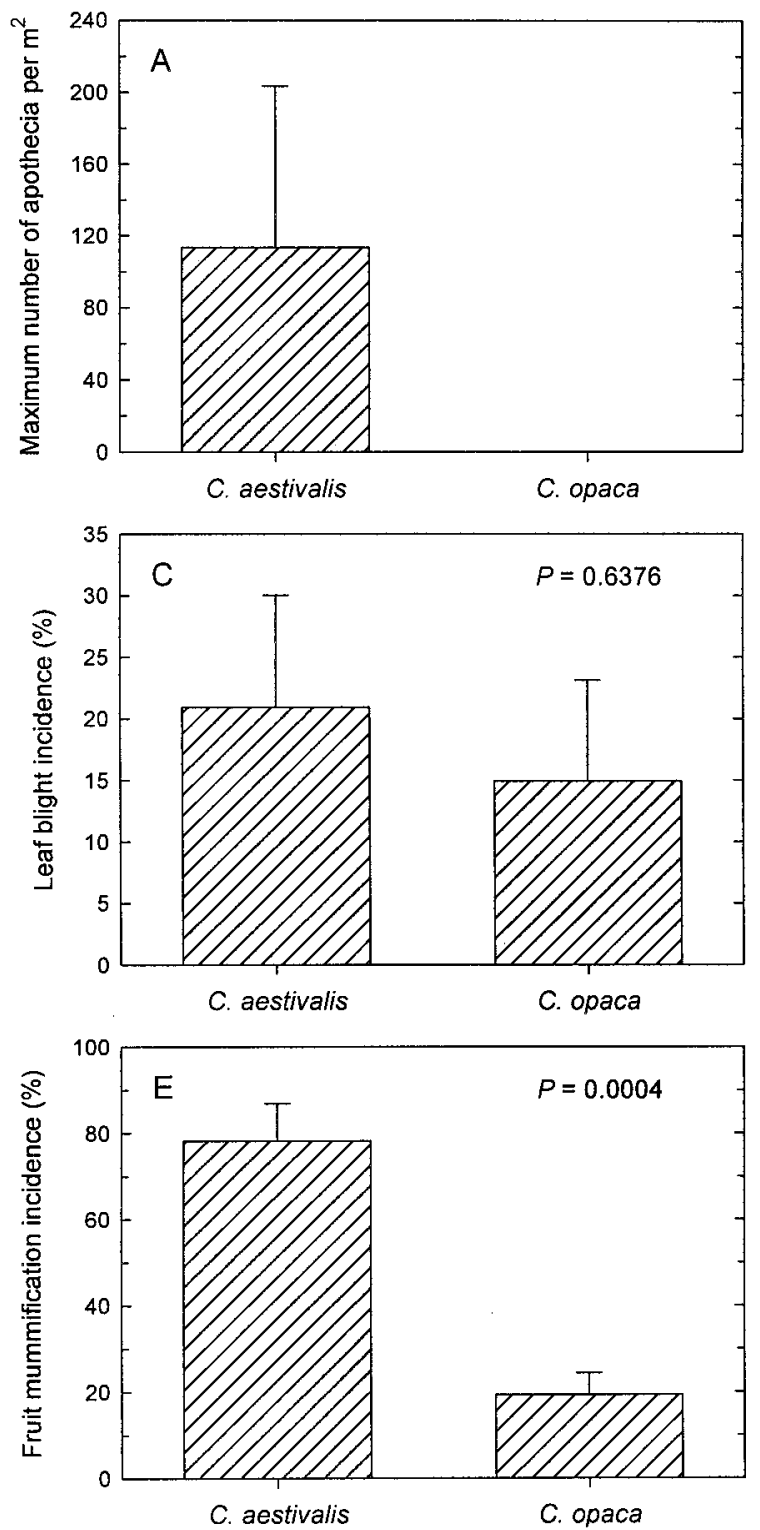

2002

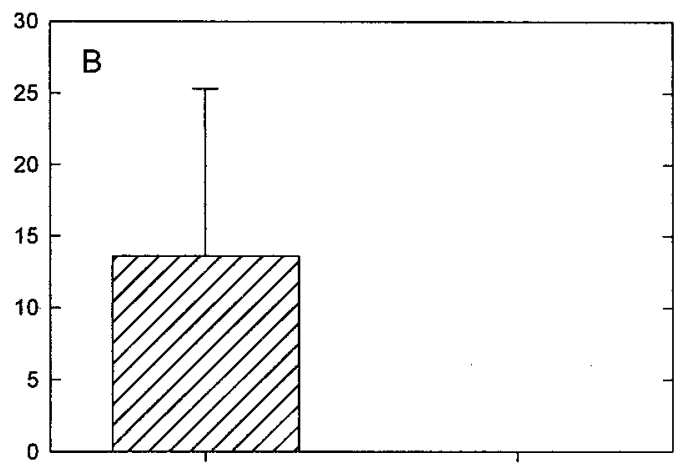

C. aestivalis

C. opaca

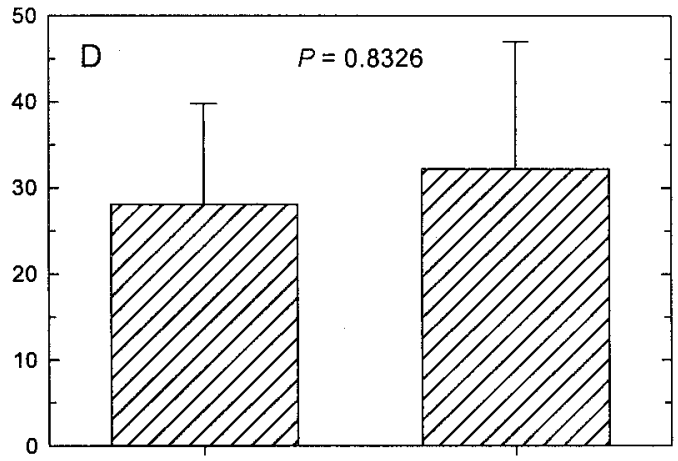

C. aestivalis

C. opaca

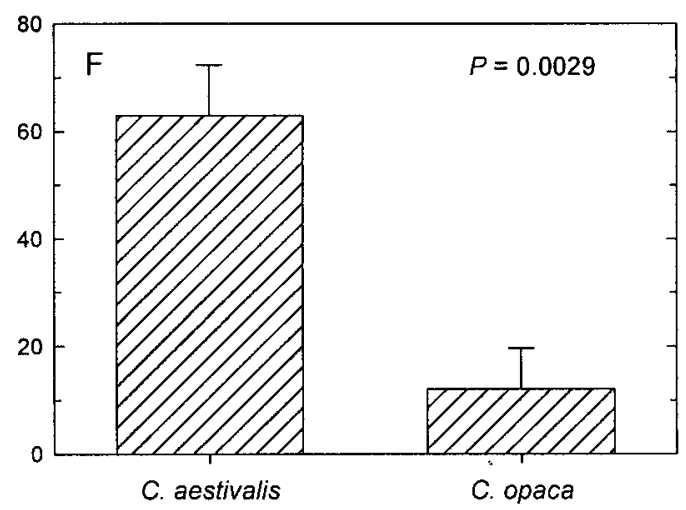

Fig. 1. A, B, Apothecial density of Monilinia johnsonii and incidence of $\mathbf{C ,}, \mathbf{D}$, leaf blight and $\mathbf{E}, \mathbf{F}$, fruit mummification in single-tree plots of Crataegus aestivalis and C. opaca mayhaws in a research orchard in southwestern Georgia in 2001 and 2002. Values are means and standard errors of five trees per species. $P$ values correspond to $t$ tests for the null hypothesis that disease variables are not significantly different between $C$. aestivalis and $C$. opaca. 
of each year, the number of apothecia in a $0.25-\mathrm{m}^{2}$ area underneath each tree was counted. Six shoots per tree were tagged and evaluated for incidence of leaf blight and fruit mummification as described above. In addition, regular phenological assessments were made by measuring leaf length to the nearest millimeter with a ruler on 24 leaves per tree and determining percent bloom based on 75 flowers per tree.

Data analysis. Using the trees as replicates, $t$ tests were applied to determine whether disease variables differed significantly $(P<0.05)$ between $C$. aestivalis and $C$. opaca. Based on per-tree averages from the 2001 and 2002 experiments, correlation and regression analyses were carried out to explore the relationships between (i) leaf length during the period apothecia were most numerous and subsequent leaf blight incidence, and (ii) incidence of leaf blight and incidence of fruit mummification. All analyses were done using procedures within the Statistical Analysis System (SAS Institute, Inc., Cary, NC).

\section{RESULTS}

2000 experiment. Blighted leaves were first observed in early March on trees of both mayhaw species; at that time, all but one tree of $C$. opaca were past $50 \%$ bloom, whereas those of $C$. aestivalis were at various earlier stages of flower development (data not shown). Final leaf disease incidence was $15.5 \pm 3.8$ (mean $\pm \mathrm{SE}$ ) and $25.3 \pm 6.4 \%$ for C. aestivalis and C. opaca, respectively; this difference was not statistically significant $(P=0.1998)$. There was, however, a significant $(P=0.0184)$ difference in the subsequent incidence of mummified fruit between $C$. aestivalis $(34.4 \pm 8.0 \%)$ and C. opaca $(12.2 \pm 3.4 \%)$. Symptomatic fruit were first observed in late March and became more numerous as healthy fruit approached maturity.

2001 and 2002 experiments. Emergence of apothecia of $M$. johnsonii was first noted on the ground underneath $C$. aestivalis trees in early and mid-February in 2001 and 2002, respectively, after accumulation of 988 and 567 chill-hours (cumulative number of hours with air temperature $<7.2^{\circ} \mathrm{C}$ since 1 October). Mature apothecia were most numerous during the second week of February in 2001 and the last decade of February in 2002. Interestingly, no apothecia were detected in plots beneath $C$. opaca canopies in either year (Fig. 1A and B). Nonetheless, subsequent leaf blight incidence was similar on the two mayhaw species (Fig. 1C and D), suggesting that ascospores from apothecia were readily dispersed within the orchard.

Across both years, two genotypes each of $C$. aestivalis (selections no. 43 and 48) and $C$. opaca (cvs. Royalty and Saline) showed very low levels of primary infection (Table 1). On a per-tree basis, final leaf blight incidence on both mayhaw spe-

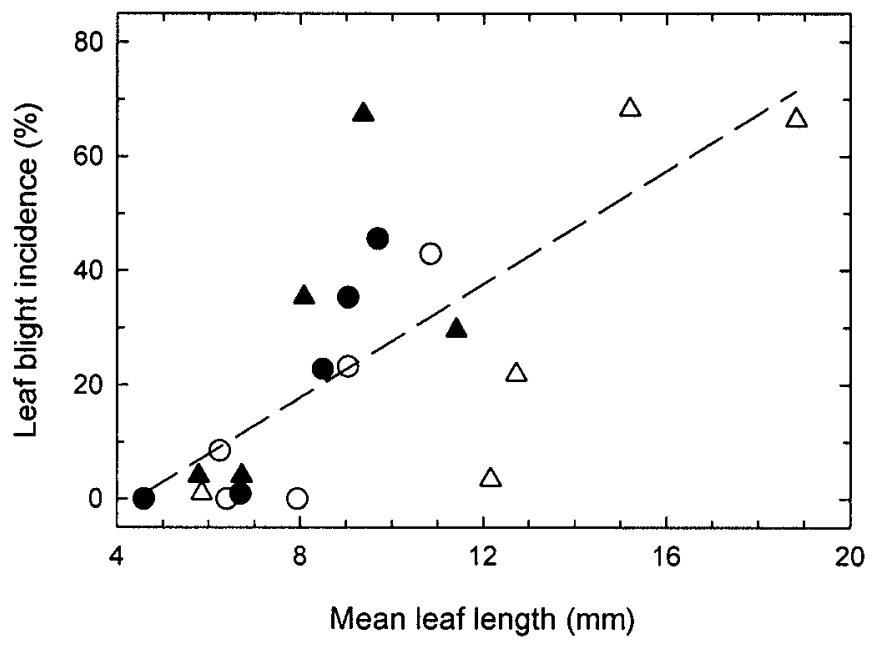

Fig. 2. Relationship between final leaf blight incidence $(y)$ and mean leaf length $(l)$ on individual mayhaw trees during the period when apothecia of Monilinia johnsonii were most numerous on the ground, based on data collected in a research orchard in southwestern Georgia in 2001 (circles) and 2002 (triangles). Solid and open symbols correspond to trees of Crataegus aestivalis and C. opaca, respectively. The regression equation corresponding to the dashed line is $y=-29.6+4.95 l\left(r^{2}=\right.$ $0.5220, P=0.0003)$.
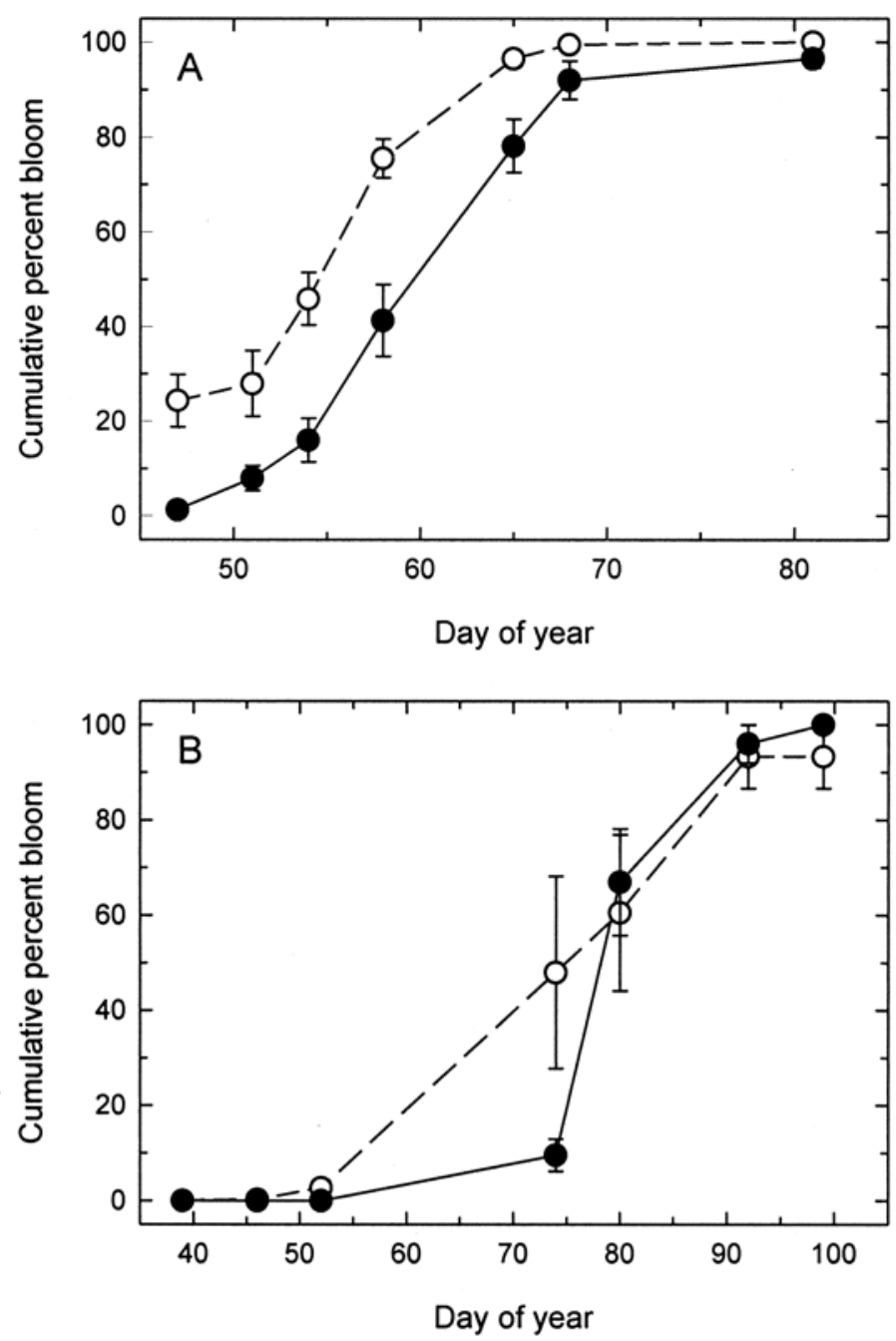

Fig. 3. Bloom progression on Crataegus aestivalis (solid symbols) and C. opaca (open symbols) mayhaws in a research orchard in southwestern Georgia in A, 2001 and $\mathbf{B}, 2002$. Values are means and standard errors of five trees per species. 
cies was positively correlated $(P<0.05)$ with mean leaf length during the period when apothecia were most numerous ( $r=$ 0.7479 and 0.8366 for $C$. aestivalis and $C$. opaca, respectively); thus, trees with earlier leaf bud break or more rapid leaf expansion were more susceptible to foliar infection (Fig. 2). Linear regression analysis indicated that slopes for the two species other $(P=0.3112)$, allowing a single regression equation to be fitted to com$\left(r^{2}=0.5220, P=0.0003\right)$, indicating that leaf blight incidence increased by approximately $5 \%$ for every $1-\mathrm{mm}$ increase in leaf length. The regression line intersected the horizontal axis at a value of $4.4 \mathrm{~mm}$, which may be interpreted as the minimum length at which leaves become infected. When making such extrapolations, however, it should be noted that there was marked scatter around the regression line (Fig. 2).

As in 2000, incidence of fruit mummification was significantly greater in C. aestivalis than in C. opaca (Fig. 1E and F). Lower fruit disease levels in C. opaca were associated with earlier bloom progression compared with $C$. aestivalis (Fig. 3) (i.e., a greater percentage of flowers completed bloom before conidia-bearing blighted leaves were present). For example, when blighted leaves were first observed in 2001 , trees of $C$. opaca were already past $75 \%$ bloom on average, whereas those of C. aestivalis were around $40 \%$ bloom. In 2002, after a low-chill winter followed by unseasonably cool temperatures during the second half of February and the first half of March, the difference in bloom progression between the two species was even more pronounced (Fig. 3). 'Elite', the mayhaw genotype with the lowest incidence of fruit mummification across both years (Table 1), was at 85.3 and were not significantly different from each bined data. The slope of the line was 4.95

$92.0 \%$ bloom when blighted leaves were first noted in 2001 and 2002, respectively.

On a per-tree basis, there was no relationship between levels of leaf blight and fruit infection for either cultivar (Fig. 4); indeed, some trees with the lowest incidence of leaf blight had the greatest incidence of fruit mummification and vice versa (Table 1). Thus, conidia may be dispersed readily from heavily blighted trees, leading to high levels of fruit infection even in trees with negligible incidence of leaf blight (Table 1).

\section{DISCUSSION}

All Monilinia spp. in the species group Disjunctoriae, of which $M$. johnsonii is a member, are characterized by a close synchrony between host and pathogen phenologies $(1,5,12)$. From an evolutionary perspective, this is dictated by the fact that both spore stages of the pathogen are capable of infection only during very short periods of host development: ascospores can infect young vegetative tissues only around bud break, whereas conidia can infect open flowers only during bloom $(1,5)$. Not surprisingly, therefore, and consistent with the early leaf and flower bud break of mayhaw in southern Georgia, key phenological stages of $M$. johnsonii occurred 1 to 3 months earlier in our study than reported from Crataegus spp. in more northern latitudes $(1,5,9,13)$.

Two epidemiological patterns observed in this study further illustrate the importance of closely synchronized host and pathogen phenologies for disease development in the mayhaw-M. johnsonii pathosystem. First, the significant positive correlation between leaf length during the period apothecia were most numerous and subsequent leaf blight incidence suggests that trees with later leaf bud break or slower rates of leaf expansion were able to escape primary infection. A similar phe-

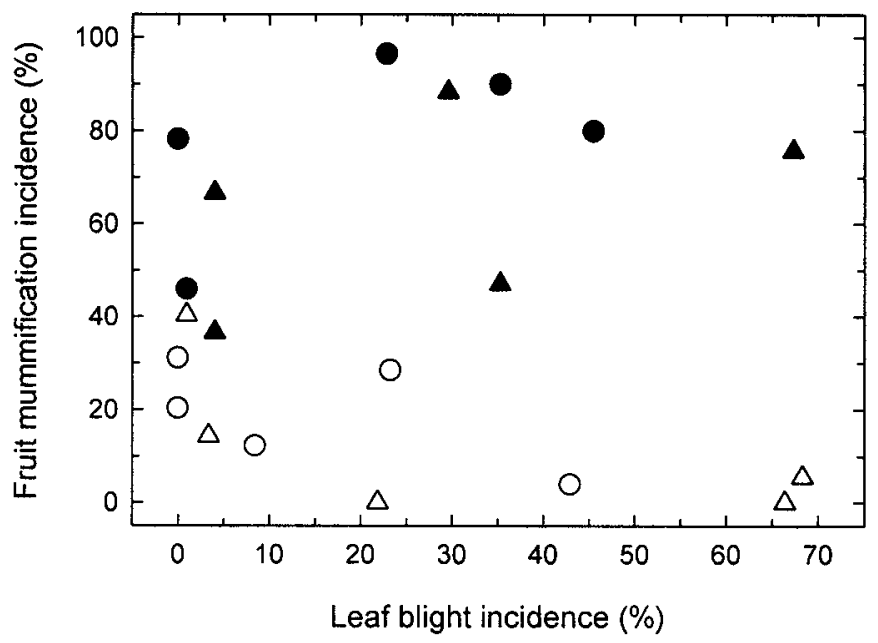

Fig. 4. Relationship between incidence levels of fruit mummification and leaf blight, caused by Monilinia johnsonii, on individual mayhaw trees in a research orchard in southwestern Georgia in 2001 (circles) and 2002 (triangles). Solid and open symbols correspond to trees of Crataegus aestivalis and C. opaca, respectively. nomenon has been described for $M$. vaccinii-corymbosi, a closely related fungus which causes shoot blight and fruit mummification on blueberry (1). In the latter pathosystem, Ehlenfeldt et al. (4) reported a positive relationship between average shoot length during the first week of ascospore release and subsequent shoot blight incidence, leading the authors to conclude that disease avoidance is responsible for at least part of the blight resistance in certain blueberry cultivars.

A second example of disease avoidance through desynchronized development of host and pathogen is indicated by the lower incidence of fruit mummification in $C$. opaca trees which, as a group, advanced through bloom earlier than those of $C$. aestivalis, thereby at least partly escaping infection. Batra (1) cited a similar phenomenon for $C$. viridis (green hawthorn) in Maryland, where levels of fruit mummification by $M$. johnsonii in a year with unusually rapid bloom progression were considerably lower than in normal years.

The significantly lower incidence of fruit mummification in $C$. opaca compared with C. aestivalis may have been responsible for the absence of apothecia in plots underneath C. opaca trees in both years. In addition, there may be differences in survival or the inherent ability to form apothecia between mummies from the two species. Apothecia are the sole source of primary inoculum of M. johnsonii; therefore, this aspect of the disease cycle warrants further investigation. Preliminary data (unpublished) indicate that apothecia can form, albeit at low levels, on mummified fruit from both species incubated in conditions conducive to carpogenic germination.

All experiments reported here were carried out in a mixed planting of $C$. aestivalis and $C$. opaca; thus, extrapolation to single genotypes of each species growing in pure stands should be made with caution. Nonetheless, our results predict that epidemics of $M$. johnsonii are less likely to be self-sustaining in pure stands of $C$. opaca than in those of $C$. aestivalis, due to partial avoidance of secondary infection and associated low numbers (or complete absence) of apothecia the following spring in the former species. Regardless of this general trend, there are genotypes within both species that almost completely avoid either primary infection or secondary infection. Planting such genotypes in pure stands should aid in minimizing losses due to the disease. Unfortunately, however, most mayhaw genotypes do not have a proven record of performance in orchard conditions and some may be pollen- or self-sterile, thus limiting the usefulness of this approach. Furthermore, planting pure stands of individual genotypes or species could select for phenologically distinct strains of the pathogen, as has been documented with the closely related $M$. vaccinii-corymbosi on blueberry (12). 


\section{ACKNOWLEDGMENTS}

We thank B. Mills and the staff at the Attapulgus Research and Education Center for cooperation in orchard maintenance and data collection, and G. Krewer and B. Rhodes for helpful discussions.

\section{LITERATURE CITED}

1. Batra, L. R. 1991. World Species of Monilinia (Fungi): Their Ecology, Biosystematics and Control. J. Cramer, Berlin.

2. Chapman, G. W., Jr., Horvat, R. J., and Payne, J. A. 1991. The nonvolatile acid and sugar composition of mayhaw fruits (Crataegus aestivalis, C. opaca, C. rufula). J. Food Qual. 14:435-439.

3. Dennis, R. W. G. 1965. The host range of Monilinia johnsonii. Plant Pathol. 14:46.

4. Ehlenfeldt, M. K., Stretch, A. W., and Brewster, V. 1996. Genetic and morphological factors affecting mummy berry blight resistance in highbush blueberry cultivars. HortScience 31:252-254.

5. Honey, E. E. 1936. North American species of
Monilinia. I. Occurrence, grouping, and lifehistories. Am. J. Bot. 23:100-106.

6. Hoogenboom, G. 1996. The Georgia Automated Environmental Network. Pages 343346 in: Preprints, 22nd Conf. Agric. Forest Meteorol. and 12th Conf. Biometeorol. Aerobiol. American Meteorological Society, Boston, MA.

7. Jing, X., Yang, Z., Zhang, Y., and Li, X. 1982. Studies on hawthorn blossom blight. I. Causal organism. Acta Phytopathol. Sin. 12:33-36.

8. Jing, X., Yang, Z., Zhang, Y., and Li, X. 1983. Studies on hawthorn blossom blight. II. Symptoms. Acta Phytopathol. Sin. 13:4144.

9. Johnson, W. T., Sinclair, W. A., and Weidhaas, J. A., Jr. 1966. Diseases and insects of hawthorns and their control. Cornell Ext. Bull. 1172, New York State College of Agriculture, Ithaca.

10. Krewer, G., and Crocker, T. 2000. Experiments and observations on growing mayhaws as a crop in south Georgia and north Florida. Coop. Ext. Serv. Publ. H-00-053, College of
Agricultural and Environmental Sciences, University of Georgia, Athens.

11. Krewer, G. W., and Crocker, T. E. 1998. Performance of mayhaws in south Georgia and north Florida. Proc. Fla. State Hortic. Soc. 110:169-171.

12. Lehman, J. S., and Oudemans, P. V. 1997. Phenology of apothecium production in populations of Monilinia vaccinii-corymbosi from early- and late-maturing blueberry cultivars. Phytopathology 87:218-223.

13. Magnus, P. 1905. Sclerotinia crataegi. Ber. Dtsch. Bot. Ges. 23:197-202.

14. Payne, J. A., Krewer, G. W., and Fitenmiller, R. R. 1990. Mayhaws: Trees of pomological and ornamental interest. HortScience 25:246, 375.

15. Phipps, J. B. 1988. Crataegus (Maloideae, Rosaceae) of the southeastern United States, I. Introduction and series Aestivales. J. Arnold Arbor. 69:401-431.

16. Scherm, H. 2001. Monilinia leaf blight and fruit mummification on mayhaw in Georgia. (Abstr.) Phytopathology 91:S80. 